\title{
IT Knowledge: What Do Accounting Students Think They Know? Do You Know More Than I Do? An Exploratory Study
}

Joel Strong, St. Cloud State University, USA

Kris Portz, St. Cloud State University, USA

\begin{abstract}
In recognition of the growing role of information technology (IT) in teaching accounting, we surveyed students at three Midwestern universities to determine their self-reported knowledge levels of 36 specific information technologies and difference in those IT knowledge levels between universities. Unlike other areas of accounting, there are no set standards for the IT curriculum for accounting education. Because of this, we expect to find significant differences in IT knowledge between these three universities. These findings are analyzed in light of authoritative guidance on appropriate accounting technology topics and research on the current status of IT in accounting education. We find accounting students have a low level of self-perceived IT knowledge. These students are not proficient in requisite technologies even after completing most of their undergraduate course work. We also find that there are significant differences in IT knowledge between the three universities in the study. These findings imply that we may be doing a disservice to accounting students and the accounting profession by not having a set IT curriculum. We conclude that it is time to assess IT knowledge and IT skill requirements necessary for accounting students and develop a standard IT curriculum in accounting education.
\end{abstract}

Keywords: Information Technology Knowledge; Accounting Students; Accounting Information Systems; Accounting Education

\section{INTRODUCTION}

OC nlike other areas of accounting, there are no set standards for the IT curriculum in accounting education. The curriculum for financial accounting is organized around Generally Accepted Accounting Principles. To be successful in financial accounting, you need to know these rules and apply them to business transactions. The curriculum for tax accounting is organized around the tax code (individual tax code or corporate tax code). To be successful in tax accounting, you need to know the tax code and how to apply it to business transactions. Finally, the curriculum for auditing is organized around Generally Accepted Auditing Standards. To be successful in auditing, you need to know GAAP and GASS and apply them to the audit of financial statements. Many accounting bodies have issued a number of documents providing guidance on the appropriate IT topics for accounting curricula (AAA 1987; IFAC 1995; AICPA 1996; AICPA 2005). Academic research has also addressed the issue of IT curricula through surveys of accounting faculty and practitioners (Heagy and Rakow 1991; Heagy and Gallun 1994; Borthick 1996; Groomer and Uday 1996; Theuri and Gunn 1998; Bain, Blankley and Smith 2002; Chang and Hwang 2003; Greenstein and McKee 2004: Cory and Pruske 2012). While we can look to these accounting bodies and academic research for some guidance, no set standards have ever been developed. Consequently, accounting programs are free to choose which IT topics are covered in accounting courses. This begs the question as to whether accounting students have adequate IT knowledge and if their level of IT knowledge is different based on where students get their accounting education. Since accounting instructors can include or omit any IT topics from their courses, we suspect that there will be significant IT knowledge differences 
across universities. The implication of this is that we may be doing a disservice to accounting students and the profession by not facilitating the IT knowledge and skills necessary to be successful. If this is the case, then maybe we have come to a point in the development of accounting education where a set curriculum for IT topics is necessary.

This paper attempts to measure and analyze self-perceived IT knowledge levels of accounting students at three AACSB-accredited Midwestern university business schools (U1, U2, and U3 respectively) and attempts to measure any differences in perceived IT knowledge levels between these three institutions. The issue of accounting student IT knowledge is important because it impacts the curriculum of all accounting courses with the greatest impact on courses that are traditionally heavy users of IT, such as accounting information systems (AIS). It also affects the level of IT knowledge accounting graduates bring to practice. Accounting education must address the needs of the profession. Therefore, accounting programs should provide consistent coverage of IT topics. If this is not the case, then we may be failing students and the profession. We find accounting students have a low level of perceived IT knowledge and that there are significant differences in perceived IT knowledge between the three universities in this study.

\section{LITERATURE REVIEW}

\section{IT Curriculum in Accounting Education Studies}

Business organizations are facing a dramatic increase of global competition and innovation. To be successful, businesses must have the ability to make good business decisions based on the large amounts of information produced by their enterprises. In this environment, it is necessary for a successful business to integrate IT into its basic processes. The result is that IT and information systems have become pervasive in today's business environment. This is particularly true for an enterprise's accounting function. The business environment demands that accountants have a high level of computer and technical skills. The International Federation of Accountants has stated that competence in information technology is imperative for the professional accountant due to it pervasive use in the business world.

Organizations want to hire college graduates in accounting who have a high level of technical skill. To meet this growing need for IT knowledge, many colleges and universities have integrated IT into the accounting curriculum. Most commonly this has been done by adding an AIS course to the curriculum. There is a body of research that considers the topics that constitute a common body of knowledge for AIS courses (AAA 1987; Davis and Leitch 1988; Heagy and Rakow 1991; Amini 1993; Borthick 1996). These studies have surveyed various accounting profession stakeholders in identifying these topics. The American Institute of Certified Public Accountants (AICPA) Core Competency Framework defines skill-based competencies for entry-level professionals. The effective use of technology is one core competency (Borkowski et. al.). The Institute of Management Accountants 2002 Practice Analysis identified computer systems and operations as one of the work activities that are expected to consume more of an internal accountants time. In sum, this body of work has provided a good framework for what IT knowledge and skills should be included in the accounting curriculum. Academic research has also pursued appropriate IT curricula through surveys of accounting faculty and practitioners (Heagy and Rakow 1991; Heagy and Gallun 1994; Borthick 1996; Groomer and Uday 1996; Theuri and Gunn 1998; Bain, Blankley and Smith 2002; Chang and Hwang 2003; Greenstein and McKee 2004; Cory and Pruske 2012). A number of academic research papers have found a particular emphasis on spreadsheets, database technology and accounting software packages (Heagy and Rakow 1991; Groomer and Uday 1996; Theuri and Gunn 1998; Bain, Blankley and Smith 2002). Accounting practitioners are much more resolute about the need for technology in the accounting curriculum and rank spreadsheet skills the highest among applications appropriate for an AIS course (Bain, Blankley, and Smith 2002).

\section{IT Knowledge Studies}

Jackson and Cherrington (2001) looked at the IT skill level of accounting students. The authors surveyed undergraduate students' skill level, preparation and importance of 17 different IT skills. Their research findings are very limited, as they had only 11 useable survey responses in their study. The general results were that students tend 
to rank their skill levels relatively low, yet the importance of the technology relatively high. Since the survey response was so low, it is difficult to draw any conclusions from this research.

Greenstein and McKee (2004) showed that audit professionals in Norway, Germany, and the United States indicate that that they have "Very Low" or "Low" levels of IT knowledge. Further studies have shown even AIS and audit professors have a self-perceived low level of knowledge of some IT topics, including e-commerce, advanced technologies, and audit automation constructs. A large number of the participants in these studies believe they received less than adequate coverage of IT in their college or university careers.

One prior study looked at the perceived IT knowledge level of accounting students. Harrast et. al. (2010) report high knowledge on the technologies that students use every day such as email, internet, word processing, presentation, spreadsheet and image processing software, with students feeling the most knowledgeable on email.

There continues to be much to learn about the specifics of IT topics within the accounting curriculum. This study attempts to provide additional insight into the growing body of research in this area. Specifically, we test students' perceived levels of IT knowledge and compare those results between three universities.

\section{RESEARCH QUESTIONS}

In this study, we examine whether accounting students perceive themselves as being knowledgeable about relevant and current IT topics and if there are any significant differences in results between universities. Specifically, two hypotheses are tested.

H1: The self-accessed perceived knowledge of relevant and current IT topics of accounting students at U1, U2, and $\mathrm{U} 3$ are low.

The first hypothesis assesses the perceived capability of accounting students to bring knowledge about relevant and current IT topics to the accounting profession after graduation.

Furthermore, we are interested in in examining the differences between the relative perceived IT knowledge levels of the three universities, and this leads us the following hypothesis:

H2: Accounting students at the three universities have the same perceived knowledge level of relevant and current IT topics.

\section{METHODS}

In an attempt to develop a comprehensive list of critical accounting technology skills, Greenstein and McKee (2004) review literature from both academic and industry research. In their literature search, 36 critical technologies were identified and used to survey faculty and practitioners. We adopt the 36 critical technologies from Greenstein and McKee (2004) because of their current and comprehensive nature, and use this list in our survey of students (See Table 1 for a description of these technologies).

Students completed a survey asking them to self-access their knowledge of 36 technologies. IT Knowledge levels were recorded by students on a seven-point scale ranging from one, for no knowledge, to seven for expert knowledge. Students completed 324 usable surveys. Information was also gathered about student demographics, internships and technological proficiency overall. Students taking the survey were accounting majors enrolled in an AIS course at one of three medium-sized, Midwestern universities with AACSB accredited business schools (See Table 2 for the list of the technologies, and their means). 


\section{RESULTS}

\section{Demographics}

We received 324 survey responses; 319 contained valid gender information identifying 51 percent of the participants as female and the remaining 49 percent as male. The mean age of participants was 23 . The sampled students consisted of 67 percent seniors, 28 percent juniors, 2 percent sophomores, and 3 percent graduate students. Fifteen percent of the sample indicated that they had completed internships. The sampled students completed a mean of 2 AIS, and 2 MIS courses. On general technology knowledge, 1 percent rated themselves very high, 18 percent rated themselves high, 62 percent adequate, 18 percent low, and 1 percent very low. We found no significant difference in the demographic variables between the three universities.

\section{Factor Analysis}

Since many of the 36 individual technologies were interrelated and overlap conceptually, we conducted a factor analysis to determine the number and character of the underlying technology constructs. After Varimax rotation, the analysis revealed six factors with eigenvalues greater than one, which accounted for $64 \%$ of the variance. Five technologies did not load strongly on any one of the constructs: work papers, data search, groupware, time billing and application service providers. Interpretation of response items comprising the six factors suggested the following constructs: advance technologies, audit automation, office automation, database, complex systems, and software. We will use these constructs to test the second hypothesis. See Table 3 for a list of the items that make up these six constructs.

Table 1. (Greenstein and McKee 2004), 36 Critical Accounting Technologies

\begin{tabular}{|c|c|c|c|}
\hline Item & $\begin{array}{c}\text { Information } \\
\text { Technology }\end{array}$ & Source & Description \\
\hline 1 & Word processing & IFAC 11 & $\begin{array}{l}\text { Computer program that facilitates entry and preparation of documents } \\
\text { such as letters or reports. }\end{array}$ \\
\hline 2 & Electronic spreadsheets & IFAC 11 & $\begin{array}{l}\text { Software that allows the auditor to enter either alphanumeric or } \\
\text { numeric data and manipulate it either via standard functions or auditor } \\
\text { programmed functions. }\end{array}$ \\
\hline 3 & E-mail & IFAC 11 & Exchange of mail messages via Intranets and/or the Internet. \\
\hline 4 & $\begin{array}{l}\text { Electronic working } \\
\text { papers }\end{array}$ & IFAC 11 & $\begin{array}{l}\text { Software that generates a trial balance, lead schedules, and other } \\
\text { schedules useful for the recording of evidence in an audit or assurance } \\
\text { engagement. }\end{array}$ \\
\hline 5 & $\begin{array}{l}\text { Internet search and } \\
\text { retrieval }\end{array}$ & AICPA (1994) & $\begin{array}{l}\text { Permits user to search text that is in electronic format and retrieve, } \\
\text { view, and print desired text. }\end{array}$ \\
\hline 6 & Image processing & $\begin{array}{l}\text { Helms and } \\
\text { Mancino (1998) }\end{array}$ & $\begin{array}{l}\text { Conversion of paper documents into electronic form through scanning } \\
\text { and the subsequent storage and retrieval of the electronic image. }\end{array}$ \\
\hline 7 & $\begin{array}{l}\text { Electronic } \\
\text { presentations }\end{array}$ & IFAC 11 & $\begin{array}{l}\text { Software that facilitates the organization and use of text, voice, and/or } \\
\text { images to communicate concepts. }\end{array}$ \\
\hline 8 & $\begin{array}{l}\text { Generalized audit } \\
\text { software }\end{array}$ & IFAC 11 & $\begin{array}{l}\text { Computer program that helps the auditor access client computer data } \\
\text { files, extract relevant data, and perform some audit function such as } \\
\text { addition or comparison. }\end{array}$ \\
\hline 9 & Expert systems & IFAC 11 & $\begin{array}{l}\text { Computer software that provides relevant information and/or decision } \\
\text { models to assist a human in making a decision or accomplishing some } \\
\text { task. }\end{array}$ \\
\hline 10 & $\begin{array}{l}\text { Embedded audit } \\
\text { modules }\end{array}$ & AICPA (1994) & $\begin{array}{l}\text { Programmed routines incorporated into an application program that } \\
\text { are designed to perform an audit function. }\end{array}$ \\
\hline 11 & $\begin{array}{l}\text { Real-time audit } \\
\text { modules }\end{array}$ & & \\
\hline 12 & $\begin{array}{l}\text { Database search and } \\
\text { retrieval }\end{array}$ & IFAC 11 & $\begin{array}{l}\text { Software that uses relational structures between data files and } \\
\text { facilitates varying data retrieval and use. }\end{array}$ \\
\hline 13 & Simulation software & Elliott (1994) & $\begin{array}{l}\text { Abstraction of some aspect of real system via software. Auditor may } \\
\text { use model to evaluate the reliability of information from real world } \\
\text { sources. This may be thought of as a very high level analytical review } \\
\text { of a company's data. }\end{array}$ \\
\hline
\end{tabular}


(Table 1 continued)

\begin{tabular}{|c|c|c|c|}
\hline 14 & $\begin{array}{l}\text { Flowcharting/data } \\
\text { modeling }\end{array}$ & AICPA (1994) & $\begin{array}{l}\text { Software using the source code version of programs to produce } \\
\text { flowcharts of program logic. }\end{array}$ \\
\hline 15 & $\begin{array}{l}\text { Computer-aided } \\
\text { systems engineering } \\
\text { tools }\end{array}$ & IFAC 11 & $\begin{array}{l}\text { Integrated package of computer tools that automate important aspects } \\
\text { of the software development process to increase software development } \\
\text { effectiveness in terms of productivity of systems development and } \\
\text { quality of developed systems. }\end{array}$ \\
\hline 16 & Encryption software & $\begin{array}{l}\text { Helms and Mancino } \\
\text { (1998) }\end{array}$ & $\begin{array}{l}\text { Changing data using some type of encoding/decoding algorithm so } \\
\text { that unauthorized persons who can access the encrypted data will not } \\
\text { be able to read it or use it. }\end{array}$ \\
\hline 17 & Groupware & $\begin{array}{l}\text { Glover and Romney } \\
\text { (1997) }\end{array}$ & $\begin{array}{l}\text { Software that permits auditors to categorize, store, and share data } \\
\text { among themselves as well as communicate with each other about that } \\
\text { data, preferably in a real-time mode. }\end{array}$ \\
\hline 18 & $\begin{array}{l}\text { Cooperative } \\
\text { client/server } \\
\text { environment }\end{array}$ & $\begin{array}{l}\text { Helms and Mancino } \\
\text { (1998) }\end{array}$ & $\begin{array}{l}\text { Distribution of processing functions between two or more computers } \\
\text { as in a local area network. This also includes end-user computing } \\
\text { where users on the network also process and store data on their } \\
\text { personal computers. }\end{array}$ \\
\hline 19 & Workflow technology & AICPA Top $10 ` 97$ & $\begin{array}{l}\text { Software and hardware that facilitates the capture of data in the work } \\
\text { place to improve management of the business. For example, using an } \\
\text { electronic scanner to record the movement of materials in a warehouse } \\
\text { based on the barcodes on the materials. }\end{array}$ \\
\hline 20 & $\begin{array}{l}\text { Database design and } \\
\text { installation }\end{array}$ & IFAC 11 & $\begin{array}{l}\text { Software that permits the creation and use of relational structures } \\
\text { between data files. }\end{array}$ \\
\hline 21 & $\begin{array}{l}\text { Time management } \\
\text { and billing systems }\end{array}$ & IFAC 11 & $\begin{array}{l}\text { Computer program that assists in capturing, managing, billing, and } \\
\text { reporting time spent on professional activities. }\end{array}$ \\
\hline 22 & Test data & IFAC 11 & $\begin{array}{l}\text { A set of transactions processed by the auditor to test the programmed } \\
\text { or procedural operations of a computer application. }\end{array}$ \\
\hline 23 & $\begin{array}{l}\text { Small business } \\
\text { accounting software }\end{array}$ & IFAC 11 & $\begin{array}{l}\text { Accounting software package used to record transactions, maintain } \\
\text { general and subsidiary ledgers, and generate financial statements. }\end{array}$ \\
\hline 24 & $\begin{array}{l}\text { Digital } \\
\text { communications }\end{array}$ & $\begin{array}{l}\text { AICPA Top } 10 \\
2000\end{array}$ & $\begin{array}{l}\text { Bandwidth - telecommunications devices used to facilitate the rapid } \\
\text { and unfettered transfer of data. }\end{array}$ \\
\hline 25 & $\begin{array}{l}\text { Tax return } \\
\text { preparation software }\end{array}$ & IFAC 11 & $\begin{array}{l}\text { Software, perhaps incorporating expert knowledge, that assists the } \\
\text { accountant/auditor in identifying relevant information, capturing and } \\
\text { recording it in a manner that can be filed with tax authorities. }\end{array}$ \\
\hline 26 & $\begin{array}{l}\text { Firewall } \\
\text { software/hardware }\end{array}$ & $\begin{array}{l}\text { AICPA Top } 10 \\
2000\end{array}$ & $\begin{array}{l}\text { Part of "security technology" that enforces an access control policy } \\
\text { between two networks. }\end{array}$ \\
\hline 27 & $\begin{array}{l}\text { User authentication } \\
\text { systems }\end{array}$ & $\begin{array}{l}\text { AIC PA Top } 10 \\
2000\end{array}$ & Devices used to verify that a system user is who he/she claims to be. \\
\hline 28 & EDI - traditional & IFAC 11 & $\begin{array}{l}\text { Transfer of data or payments electronically between computers using } \\
\text { software that may, or may not, require human intervention to affect } \\
\text { the transfer. }\end{array}$ \\
\hline 29 & EDI - web based & $\begin{array}{l}\text { Greenstein and } \\
\text { Feinman }(2000)\end{array}$ & The extension to SML-based EDI \\
\hline 30 & $\begin{array}{l}\text { Wireless } \\
\text { communications }\end{array}$ & $\begin{array}{l}\text { AICPA Top } 10 \\
2000\end{array}$ & $\begin{array}{l}\text { The ability to transfer digital data without the use of cables, twisted- } \\
\text { pair, or fiber optics. }\end{array}$ \\
\hline 31 & Agent technologies & $\begin{array}{l}\text { AICPA Top } 10 \\
2000\end{array}$ & $\begin{array}{l}\text { Programmed modules that are given certain levels of authority and } \\
\text { autonomy to act on behalf of their "supervisor", such as to decide } \\
\text { whether to order more inventory and from which supplier. }\end{array}$ \\
\hline 32 & $\begin{array}{l}\text { Intrusion detection } \\
\text { and monitoring }\end{array}$ & $\begin{array}{l}\text { AICPA Top } 10 \\
2000 \text { and Greenstein } \\
\text { and Feinman }(2000)\end{array}$ & $\begin{array}{l}\text { Part of "security technology" that identifies unauthorized requests for } \\
\text { services. }\end{array}$ \\
\hline 33 & $\begin{array}{l}\text { Internal network } \\
\text { configurations }\end{array}$ & IFAC 11 & $\begin{array}{l}\text { Linkage of individuals and data through hardware and software } \\
\text { systems that permit the exchange of various types of data. }\end{array}$ \\
\hline 34 & $\begin{array}{l}\text { External network } \\
\text { configurations }\end{array}$ & $\begin{array}{l}\text { AICPA Top } 10 \\
2000\end{array}$ & $\begin{array}{l}\text { Intranet, extranet, and Internet access devices that enable users } \\
\text { physically separated from the server to access it. }\end{array}$ \\
\hline 35 & $\begin{array}{l}\text { Enterprise resource } \\
\text { planning }\end{array}$ & McKee (2000) & Business-wide information systems that cross boundaries. \\
\hline 36 & $\begin{array}{l}\text { Application service } \\
\text { providers }\end{array}$ & McKee (2000) & $\begin{array}{l}\text { Companies that host (provide hardware, software and connectivity) for } \\
\text { specific business applications. }\end{array}$ \\
\hline
\end{tabular}


Table 2. Student Mean Perceived Technology Knowledge and Descriptive Statistics by Mean Knowledge Level

\begin{tabular}{|c|c|c|c|c|c|}
\hline Rank* & Technology & Overall & Univ. 1 & Univ. 2 & Univ. 3 \\
\hline 1 & Email & 5.90 & 5.82 & 6.00 & 6.33 \\
\hline 2 & Internet Srch & 5.76 & 5.72 & 5.76 & 6.10 \\
\hline 3 & Word Proc & 5.51 & 5.44 & 5.55 & 6.00 \\
\hline 4 & Presentation & 5.09 & 5.12 & 4.95 & 5.38 \\
\hline 5 & Sprdsheet & 4.76 & 4.62 & 4.85 & 5.71 \\
\hline 6 & Image Proc & 4.46 & 4.40 & 4.45 & 5.10 \\
\hline 7 & DB Search & 3.75 & 3.73 & 3.73 & 4.05 \\
\hline 8 & Wireless & 3.77 & 3.90 & 3.33 & 4.33 \\
\hline 9 & Flowcharting & 3.57 & 3.62 & 3.76 & 2.24 \\
\hline 10 & Wrkpapers & 3.57 & 3.52 & 3.60 & 3.86 \\
\hline 11 & SB Account & 3.19 & 3.37 & 2.65 & 3.90 \\
\hline 12 & Tax software & 3.03 & 3.05 & 2.79 & 3.76 \\
\hline 13 & DB Design & 2.91 & 2.99 & 2.96 & 1.90 \\
\hline 14 & Firewall & 2.82 & 2.79 & 2.83 & 3.10 \\
\hline 15 & Time Billing & 2.70 & 2.72 & 2.63 & 2.81 \\
\hline 16 & ERP & 2.54 & 2.57 & 2.26 & 3.52 \\
\hline 17 & Simulation & 2.52 & 2.63 & 2.32 & 2.33 \\
\hline 18 & GAS & 2.52 & 2.79 & 1.94 & 2.50 \\
\hline 19 & Digital Com & 2.44 & 2.58 & 2.18 & 2.14 \\
\hline 20 & Internal Net & 2.35 & 2.41 & 2.16 & 2.57 \\
\hline 21 & User Auth & 2.34 & 2.42 & 2.22 & 2.05 \\
\hline 22 & EDI Web & 2.33 & 2.38 & 2.35 & 1.71 \\
\hline 23 & External Net & 2.32 & 2.36 & 2.18 & 2.57 \\
\hline 24 & Work Flow & 2.29 & 2.36 & 2.14 & 2.29 \\
\hline 25 & EDI Trad'l & 2.23 & 2.24 & 2.34 & 1.62 \\
\hline 26 & Client Serv & 2.22 & 2.22 & 2.08 & 2.81 \\
\hline 27 & CASE & 2.18 & 2.20 & 2.32 & 1.43 \\
\hline 28 & Test Data & 2.14 & 2.26 & 1.93 & 1.86 \\
\hline 29 & Expert Sys & 2.04 & 2.13 & 1.81 & 2.29 \\
\hline 30 & Agent Tech & 2.03 & 2.12 & 1.95 & 1.48 \\
\hline 31 & ASP & 2.01 & 2.13 & 1.77 & 1.76 \\
\hline 32 & Groupware & 2.00 & 1.92 & 2.14 & 2.14 \\
\hline 33 & Intrusion & 1.98 & 2.13 & 1.70 & 1.71 \\
\hline 34 & RT Aud Mod & 1.84 & 1.91 & 1.75 & 1.57 \\
\hline 35 & Encryption & 1.80 & 1.87 & 1.68 & 1.67 \\
\hline 36 & Embedded AM & 1.78 & 1.87 & 1.67 & 1.43 \\
\hline
\end{tabular}

*The ranking is based on the overall mean knowledge level. 


\section{Test of H1 Perceived IT Knowledge Level}

To examine the first hypothesis, a benchmark is needed against which to measure the reported knowledge levels for the set of IT skills. Similar to Greenstein-Porsch et. al. (2008), we chose the midpoint of the response range as the benchmark. Using a seven-point Likert scale, the midpoint is 3.5. For accounting students from U1, 26 of the $36(72 \%)$ IT skills are below the midpoint; for accounting students from U2, 26 of the $36(72 \%)$ IT skills are below the midpoint; and for accounting students from U3 24 of the $36(67 \%)$ IT skills are below the midpoint.

We used the six components found in factor analysis to determine if the accounting students were more or less knowledgeable on the six constructs. The following results are found for accounting students from U1:

Advance technologies- $-\mathrm{H} 1$ reject, $92 \%$ below the midpoint.

Audit automation- $\mathrm{H} 1$ reject, $100 \%$ below the midpoint.

Office automation-H1 accept, $100 \%$ above the midpoint.

Database- $-\mathrm{H} 1$ reject, $67 \%$ below the midpoint.

Complex systems-H1 reject, $100 \%$ below the midpoint.

Software-H1 reject, $67 \%$ below the midpoint.

The following results were found for accounting students from U2:

Advance technologies- $\mathrm{H} 2$ reject, $100 \%$ below the midpoint.

Audit automation- $\mathrm{H} 2$ reject, $100 \%$ below the midpoint.

Office automation- $\mathrm{H} 2$ accept, $100 \%$ above the midpoint.

Database- $-\mathrm{H} 2$ reject, $67 \%$ below the midpoint.

Complex systems- $-\mathrm{H} 2$ reject, $100 \%$ below the midpoint.

Software- $-\mathrm{H} 2$ reject, $67 \%$ below the midpoint.

The following results were found for accounting students from U3:

Advance technologies- $-\mathrm{H} 3$ reject, $85 \%$ below the midpoint.

Audit automation- $\mathrm{H} 3$ reject, $100 \%$ below the midpoint.

Office automation-H3 accept, $100 \%$ above the midpoint.

Database- $-\mathrm{H} 3$ reject, $100 \%$ below the midpoint.

Complex systems-H3 reject, $50 \%$ below the midpoint.

Software-H3 reject, $100 \%$ below the midpoint.

Based on the hypothesis test, the only construct for which the accounting students from all three universities have a knowledge level above the midpoint is office automation. This construct is made up of word processing, email, internet search and retrieval, image processing, and electronic presentations. It is not surprising accounting students have a high knowledge level for these technologies. Students have probably been using these technologies since junior high school. By the time these students enter the accounting major they are quite skilled at these technologies.

For all the other constructs, the mean knowledge level is below the midpoint. However, looking at the individual items that make up these constructs we identified five specific technologies with means greater than the midpoint. They are database search, spreadsheets, flowcharting, wireless technology, and electronic work papers.

There has been a call for accounting professionals to be able to query electronic databases (AICPA 1999). Research shows that database skills are highly regarded by accounting faculty and professionals (Bain, Blankley and Smith 2002) although research shows that CPA firms place less emphasis on database skills than corporations and government (Theuri and Gunn 1998). In a review of syllabi, Baine et. al. (2002) found that the most frequent AIS projects were database related and that about 36 percent of AIS classes involve the use of database software or projects (Bain, Blankley and Smith 2002). Chang and Hwang (2003) show that educators plan to teach databases second only to information security and internal control in AIS courses. Perhaps part of the low reported database 
knowledge is due not to insufficient instruction, but rather to the complexity of the technology (Harrast et. al. 2010). In our experience with teaching database technology, we have found that even databases designed for end-user development are highly complex and represent a major paradigm shift from other office suite applications (Harrast et. al. 2010).

Table 3. Student Competency in Critical Accounting Technologies Grouped by Factor Analysis

Factor: Underlying technologies

\begin{tabular}{|c|c|c|c|c|c|}
\hline $\begin{array}{c}\text { Advanced } \\
\text { technologies }\end{array}$ & $\begin{array}{c}\text { Audit } \\
\text { automation }\end{array}$ & $\begin{array}{c}\text { Office } \\
\text { automation }\end{array}$ & Database & Complex Systems & Software \\
\hline $\begin{array}{l}\text { - Cooperative } \\
\text { client/server } \\
\text { environment } \\
\text { - Workflow } \\
\text { technology } \\
\text { - Test Data } \\
\text { - Digital } \\
\text { communications } \\
\text { - Firewall } \\
\text { software/hardwar } \\
\text { e } \\
\text { - User } \\
\text { authentication } \\
\text { systems } \\
\text { - EDI - traditional } \\
\text { EDI - web based } \\
\text { - Wireless } \\
\text { communications } \\
\text { - Agent } \\
\text { technologies }\end{array}$ & $\begin{array}{l}\text { - Generalized audit } \\
\text { software } \\
\text { - Expert Systems } \\
\text { - Embedded audit } \\
\text { modules } \\
\text { - Real-time audit } \\
\text { modules } \\
\text { - Simulation } \\
\text { Software }\end{array}$ & $\begin{array}{l}\text { - Word processing } \\
\text { - E-mail } \\
\text { - Internet search } \\
\text { and retrieval } \\
\text { - Image processing } \\
\text { - Electronic } \\
\text { presentations }\end{array}$ & $\begin{array}{l}\text { - Flowcharting/data } \\
\text { modeling } \\
\text { - Computer-aided } \\
\text { systems } \\
\text { engineering tools } \\
\text { - Database design } \\
\text { and installation }\end{array}$ & $\begin{array}{l}\text { - Encryption } \\
\text { Software } \\
\text { - Enterprise } \\
\text { resource planning } \\
\end{array}$ & $\begin{array}{l}\text { - Electronic spread- } \\
\text { sheets } \\
\text { - Small business } \\
\text { accounting } \\
\text { software } \\
\text { - Tax return } \\
\text { preparation } \\
\text { software }\end{array}$ \\
\hline
\end{tabular}

It is U1s experience that professional accounting firms and other businesses desire accounting graduates with spreadsheet skills. U1 has been advising students to take a standalone Microsoft Excel class as part the of the 150-hour rule. We have also noted that more of our accounting major classes are including spreadsheet projects as part of course requirements, including intermediate accounting, managerial accounting, and auditing.

Due to the Sarbanes-Oxley Act of 2002 flowcharting has become a more important topic in accounting as a means to document internal controls. Flowcharting is including in the AIS courses at all three universities included in this research study. With the growth of wireless access to corporate intranets and the Internet, this technology is beginning to be included in more accounting information system textbooks. Finally, electronic work papers are being used by more and more accounting firms to document their audit procedures. Auditing textbooks are beginning to include greater coverage of electronic work papers.

\section{Test of H2 Perceived IT Knowledge Level Differences}

In the previous section, we found that the perceived IT knowledge of accounting students at the three Midwest universities were on the low side of a seven-point Likert scale. In this section, the relative perceived IT knowledge differences between the three groups is examined. We used the six components found in factor analysis to determine if there are IT knowledge differences between the three schools. We performed a two-step process. First we ran a one-way ANOVA to compare the means of the three universities and identify any significant differences (see Table 4). 
The following results are found.

Advance technologies- $-\mathrm{H} 4$ accept.

Audit automation- $\mathrm{H} 4$ reject.

Office automation- $-\mathrm{H} 4$ reject.

Database- $-\mathrm{H} 4$ reject.

Complex systems-H4 reject.

Software- $\mathrm{H} 4$ reject.

Next, we performed a post hoc test comparing the means using Tukey's HSD test.

Based on the hypothesis test, there are significant IT knowledge differences between the students at the three universities for five of the six constructs. For advanced technologies, there were no significant differences in knowledge level between the universities. For the audit automation construct, U1 reports higher levels of knowledge for $80 \%$ of the items. For the office automation, complex systems and software constructs, U3 reports higher levels of knowledge for $100 \%$ of the items. Finally, for database, U2 reports higher levels of knowledge for $100 \%$ of the items.

Specifically the analysis of the results revealed the following:

- For the construct audit automation, all three universities have low levels of knowledge. However, U2 has a significantly lower level on three of the five items, and U3 has a significantly lower level on two of the five items that make up this construct compared to U1.

- $\quad$ For the construct office automation, all three universities have high levels of knowledge. However, U1 has a significantly lower level on four of the five items and U2 has a significantly lower level on one of the five items that make up this construct compared to U3.

- $\quad$ For the construct database, all three universities have low levels of knowledge. However, U3 has a significantly lower level on all three items that make up this construct compared to U1 and U2.

- For the construct complex, all three universities have low levels of knowledge. However, U3 has a significantly lower level on one of the two items that make up this construct compared to U1.

- $\quad$ For the construct software, all three universities have low levels of knowledge. However, U1 and U2 have a significantly lower level on all three items that make up this construct compared to U3.

ANOVA

Table 4. Accounting Knowledge Differences

\begin{tabular}{|c|c|c|c|c|c|c|}
\hline & & Sum of Squares & df & Mean Square & $\mathbf{F}$ & Sig. \\
\hline \multirow{3}{*}{ AdvTech } & Between Groups & 2.376 & 2 & 1.188 & .997 & .370 \\
\hline & Within Groups & 359.810 & 302 & 1.191 & & \\
\hline & Total & 362.187 & 304 & & & \\
\hline \multirow{3}{*}{ AuditAuto } & Between Groups & 8.514 & 2 & 4.257 & 3.730 & .025 \\
\hline & Within Groups & 360.602 & 316 & 1.141 & & \\
\hline & Total & 369.116 & 318 & & & \\
\hline \multirow{3}{*}{ OfficeAuto } & Between Groups & 4.277 & 2 & 2.139 & 3.086 & .047 \\
\hline & Within Groups & 218.956 & 316 & .693 & & \\
\hline & Total & 223.233 & 318 & & & \\
\hline \multirow{3}{*}{ DataBase } & Between Groups & 24.230 & 2 & 12.115 & 10.119 & .000 \\
\hline & Within Groups & 378.337 & 316 & 1.197 & & \\
\hline & Total & 402.568 & 318 & & & \\
\hline \multirow{3}{*}{ CompSys } & Between Groups & 8.217 & 2 & 4.108 & 3.640 & .027 \\
\hline & Within Groups & 356.642 & 316 & 1.129 & & \\
\hline & Total & 364.859 & 318 & & & \\
\hline \multirow{3}{*}{ Software } & Between Groups & 18.719 & 2 & 9.359 & 7.412 & .001 \\
\hline & Within Groups & 396.495 & 314 & 1.263 & & \\
\hline & Total & 415.213 & 316 & & & \\
\hline
\end{tabular}




\section{SUMMARY AND IMPLICATIONS}

The primary purpose of this study was to determine if there were any significant differences between IT knowledge for accounting students from three different universities. We began by measuring the perceived level of 36 IT topics of accounting students. We find that the accounting students in this study have an overall low level of perceived IT knowledge. The results were consistent across all three schools. For accounting students from U1, 26 of the $36(72 \%)$ IT skills are below the midpoint; for accounting students from U2, 26 of the $36(72 \%)$ IT skills are below the midpoint; and for accounting students from U3, 24 of the $36(67 \%)$ IT skills are below the midpoint. Based on the hypothesis test, the only construct for which the accounting students from all three universities have a knowledge level above the midpoint is office automation. For all the other constructs, the mean knowledge level is below the midpoint.

Based on the level of IT knowledge we measured, the results also indicate that there are significant differences in perceived IT knowledge between the three universities in this study for five of the six constructs studied. This indicates that an accounting students' perceived level of accounting knowledge is a factor of where he or she attends college. Since there is no set standard curriculum for IT knowledge in accounting education, and faculty can teach whatever IT they want, we expected to see significant differences and we did.

The implications of this are that we may be doing a disservice to accounting students and the profession. We may not be facilitating the IT knowledge and skills necessary to be successful. If this is the case, then maybe we have come to a point in the development of accounting education were we need to define a set curriculum for technology. This process of assessment is very important in determining if we are meeting the requirements of our stakeholders. Are our students developing the IT skills that are necessary or even demanded by the current business environment?

\section{LIMITATIONS}

As is common with all types of research, this study has a number of possible limitations that may limit the validity of the results. An understanding of these limitations will help the reader to make correct interpretations of the results of this study. The 36 technologies examined in this research were subjectively selected by Greenstein and McKee (2004). Some equally significant technologies may have been inadvertently overlooked in the literature and, thus, are not included in this research nor considered in the discussion. The respondents in this study selfreported views about their IT knowledge. They may, however, hold incorrect views about their knowledge of these technologies and their actual knowledge may be higher or lower than what was reported. Another limitation, as previously acknowledged, is that many of the technologies overlap conceptually. We attempted to overcome this limitation by conducting factor analysis and identifying constructs by examining aggregated items by construct.

\section{FUTURE RESEARCH}

Future research needs to be conducted to determine what IT topics and skills should be part of the accounting curriculum and in what mix. We should look to all the stakeholders in this assessment, including, students, faculty, accounting organizations, and businesses. We need to determine what IT knowledge will allow our students to be successful in their education and their professional life after graduation.

\section{AUTHOR INFORMATION}

Joel Strong is a professor of accounting at St. Cloud State University. He holds a PhD in accounting from the University of Nebraska - Lincoln and teaches courses in intermediate accounting and auditing. His research interests are in behavioral accounting and accounting education. His research has appeared in Advances in Accounting, Research in Governmental and Nonprofit Accounting, The Accounting Educators' Journal, and The Review of Business Information Systems. E-mail: jmstrong@stcloudstate.edu

Kris Portz is a professor of accounting at St. Cloud State University. She holds a $\mathrm{PhD}$ in accounting from the University of Nebraska - Lincoln and teaches courses in intermediate accounting and international accounting. Her 
research interests are in managerial accounting, international accounting, and accounting education. Her research has appeared in American Journal of Business, Journal of International Business Discipline, CMA Management Journal, and Review of Business Information Systems. E-mail: kportz@stcloudstate.edu

\section{REFERENCES}

AICPA (1994). Information Technology Competencies in Accounting Profession: AICPA Implementation Strategies for IFAC International Education Guideline No. 11, AICPA, New York, NY.

AICPA (2002). The CPA Vision Project: 2011 and Beyond, AICPA, New York, NY.

AICPA (2000). Top Ten Technologies, AICPA, New York, NY.

American Accounting Association (AAA) (1987). Committee on contemporary approaches to teaching accounting information systems (The Mock Commission). Journal of Information Systems, Vol. 2 No. 1, 127-56.

American Institute of Certified Public Accountants (AICPA) (2005). The AICPA Core Competency Framework for Entry into the Accounting Profession. Available at: http://www.aicpa.org/edu/corecomp.htm.

Amini, M.S. (1993). Assessing Computing Literacy of Business Students Regional University. Journal of IS Education, Vol. 5 No. 3, 23-34.

Arens, A.A. (2004). Computerized Auditing Using ACL Software. Armond Dalton, Okemos, MI.

Arens, A.A. and Ward D. D. (2006). Computerized accounting using Microsoft business solutions - Great Plains 8.0. $3^{\text {rd }}$ Edition, Armond Dalton, Okemos, MI.

Bain, C. E., Blankley, A. I. and Smith, L. M. (2002). An examination of topical coverage for the first accounting information systems course. Journal of Information Systems, Vol. 16 No. 2, pp 143-64.

Borkowski, S.C., Bukics, R.M. and Welsh, M.J. (2007). Technology generation upgrades: are educators and employers on the same page. Pennsylvania CPA Journal. Vol. 78 Issue 3, p.22 - 27

Borthick, A. F. (1996). Helping accountants learn to get the information managers want: The role of the accounting information systems course. Journal of Information Systems, Vol. 10 No. 2, pp. 75-85.

Chang, C. J. and Hwang, N. R. (2003). Accounting education, firm training and information technology: a research note. Accounting Education, Vol. 12 No. 4, pp. 441-50.

Cory, S.N., and Pruske, K. A. (2012). Necessary skills for accounting graduates: An exploratory study to determine what the profession wants. Proceedings of ASBBS, Vol. 19 No. 1, pp. 208-218.

Davis, J. R., and Leitch, R. A. (1988). Accounting information systems courses and curricula: New perspectives. Journal of Information Systems, Vol. 2 No. 2, pp. 153-66.

Doost, R.K. (2002). The need for change in the way we teach accounting information systems. Managerial Auditing Journal, Vol. 17 No. 5, pp. 277-82.

Elliot R.K. (1994). Confronting the future: choices for the attest function. Accounting Horizons, September, pp. 1124.

Greenstein, M. and Feinman T. (2000). Electronic commerce: security, risk, management, and control. McGrawHill, New York, NY.

Greenstein, M. and McKee, T. M. (2004). Assurance practitioners' and educators' self-perceived IT knowledge level: an empirical assessment. International Journal of Accounting Information Systems, Vol. 5 No. 2, pp. $213-43$.

Greenstein-Prosch M., McKee, T.E. and Quick, R. (2008). Comparison of the information technology knowledge of United States and German Auditors. The International Journal of Digital Accounting Research, Vol. 8. pp. 45-79.

Groomer, S. M., and Murthy, U. S. (1996). An empirical analysis of the accounting information systems course. Journal of Information Systems, Vol. 10 No. 2, pp. 103-27.

Harrast, S., Strong, J., and Bromley, R. (2010). More accounting theory or more information technology? The Accounting Educators' Journal, Vol. XX, pp. 1 - 19.

Heagy, C.D. and Gallun, R. A. (1994). Recommended microcomputer knowledge for accounting graduates: a survey. Journal of Accounting Education, Vol. 12 No. 3, pp. 205-10.

Heagy, C.D., and Rakow E. A. (1991). Course content of accounting information systems: Do professors agree? Accounting Educator's Journal, Vol. 3 Winter, pp. 140-58.

Helms G.L. and Mancino j. (1998). The electronic auditor-wave goodbye to the paper trail. J Account, April, pp. 48-8.

International Federation of Accountants (IFAC) (1995). Information Technology in Accounting Curriculum, IFAC 
International Education Guideline No. 11. IFAC, New York, NY.

Jackson, R.B. and Cherrington, J. O. (2001). IT Instruction Methodology and Minimum Competency for Accounting Students. Journal of Information Systems Education, Vol. 12 No. 4, pp. 213-22.

Levitan, A.S. (1988). Using a data base management system in an accounting information systems course. Journal of Information Systems, Vol. 2 No. 1, pp. 73-8.

McCarthy, W.E. (2004). The REA modeling approach to teaching accounting information systems. Issues in Accounting Education, Vol. 18 No. 2, pp. 427-41.

McKee T.E. (2000). Accounting/auditing in Norway. Oslo, Norway: The Norwegian Institute of Public Accountants.

Perry, J.T. and Schneider, G. P. (2003). Building Accounting Systems Using Access 2002, Thomson/South-western.

Rittenberg, L.E. and Schwieger, B. J. (2002). Auditing: Concepts for a Changing Environment with IDEA Software, Thomson/South-Western.

Russell, K.A., Siegel, G. H. and Kulesza, C. S. (1999). Counting More, Counting Less: Transformations in the Management Accounting Profession. Management Accounting, September, p. 38.

Singh, S. 1999. The code book, New York: Doubleday.

Theuri, P.M. and Gunn, R. (1998). Accounting information systems course structure and employer systems skills expectations. Journal of Accounting Education, Vol.16 No. 1, pp. 101-21.

The Institute of Management Accountants (2002). The 2002 Practice Analysis of Management Accounting. The Institute of Management Accountants, Montvale, NJ. 